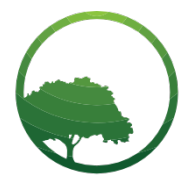

Research in Business \& Social Science

IJRBS VOL 8 NO 5 ISSN: 2147-4478

\title{
Entrepreneurial opportunity discovery dimensions and growth of non- governmental organizations in Kenya
}

\author{
Olive Kamene Ndeveni Tindika ${ }^{a^{*}}$, Kenneth Lawrence Wanjau ${ }^{b}$, \\ George Mbugua Kariukic, Joseph Muchirid \\ ${ }^{a, b, d}$ Business and Economics Department, Karatina University, P.O Box 1957-10101, Karatina; Kenya \\ ${ }^{c}$ Econometrics and Statistics Department, Kenyatta University, Kenya.P.O Box 43844-00100, Nairobi, Kenya
}

\author{
ARTICLE INFO \\ Article history: \\ Received 02 July 19 \\ Accepted 01 August 19

\section{Keywords:} \\ Opportunity Discovery \\ Kirzner theory \\ Structural Equation Model \\ NGOs \\ JEL Classification: \\ L19
}

Received in revised form 23 July 19

\begin{abstract}
A B S T R A C T
Non-Governmental Organizations (NGOs) play a critical role in addressing social ills like poverty, employment, and food insecurity; therefore, their growth prospects enhance their ability to address these social ills. Discovery of entrepreneurial opportunities amongst the agro-based NGOs has not got the desired attention, and it is the least researched area in social entrepreneurship. This study investigated the relationship between Entrepreneurial Opportunity Discovery Dimensions and Growth of Non-Governmental Organizations in Kenya. It employed correlation design and was anchored on the Kirznerian Entrepreneurship Theory. The target population was 135 agro-based NGOs in Kenya. A mixed-method approach was used, combined qualitative and quantitative techniques. Statistical Package for Social Sciences (SPSS) version 21 and Analysis of Moment Structures (AMOS graphic25) aided in the analysis. Structural Equation Modeling (SEM) using AMOS and Simple linear regression analysis were the primary analysis techniques used to evaluate the relationship between entrepreneurial opportunity discovery dimensions and the growth of $N G O s$. The results indicated that alertness0.372, $p=0.033)$ and prior knowledge $(0.163, p=0.031)$ have a significant favorable influence on growth, while social networks 0.047, $p=0.713$ ) showed an insignificant effect on the growth of NGOs. Investing in acquiring alert individuals and helping them gain relevant knowledge in the $21^{\text {st }}$ technologies and emerging issues can lead to increased NGO ability to continue serving the community effectively and be engines of development for the general good of Kenya.
\end{abstract}

\section{Introduction}

Fundamentally, Non-governmental organizations world over, plays a critical role as intermediaries of aid between the funding community on one side and beneficiaries on the other side. The overriding objective of Non-Governmental Organizations is to help out society to overcome the challenges due to poverty, unprecedented climatic calamities and advocacy Duffield, (2012). There is evidence of increased advocacy activities and the 'watchdog' role of NGOs, an indication of their rising importance addressing citizen concerns.

A lot of NGOs spends time and money marketing themselves and this has led to unprecedented increased competition for donations among NGOs, this has made bigger NGOs typically spend up to $10 \%$ of their funds on marketing and fundraising with positive and negative consequences accompanying this competition (Aldashev \& Navarra, 2018). One of the negative consequences of competition is that a project may not be located in the right place for example in the poorest areas where the likelihood of project

\footnotetext{
* Corresponding author. Tel: +254-728-330-108 ORCID ID: 0000-0003-0804-7455 Peer review under responsibility of Bussecon International Academy. (C) 2019 Bussecon International. Hosting by SSBFNET- Center for Strategic Studies in Business \& Finance. All rights reserved. https://doi.org/10.20525/ijrbs.v8i5.300
} 
success is lower. This calls for some self-regulatory mechanisms among the NGOs to avert it. Alternatively, innovation and entrepreneurial behaviors are strategies most organizations adopt in the wake of stiff competition (Bloom \& Chatterji, 2009).

The NGOs therefore compete to raise funds and use the limited allocations diligently from donors and other philanthropic organization to come with initiatives in agriculture that help communities to produce and compete in local and global markets. They also encourage rural innovation and helps local users' access global information. The growth of these NGOs determine their continued capacity to serve the community in future because a growing NGOs is not only able to create more opportunities but also able to attract funding for its survival and extended ability to meet community expectations. This is shown by an increased in private donations to charities in the last decades, (Atkinson et al., 2012). Due to the competition for attention from funding partners, there is increased need for entrepreneurial mindset among the NGOs in order to be more competitive to discover and exploit opportunities. Discovering and taking advantage of opportunities that others don't see is key to developing the competitive edge for any organization. Shane and Venkataraman (2000) retaliated that organizations with adequate skills to spot and seize opportunities which others don't see create a competitive edge. This requires an organization with a pro entrepreneurial environment with a critical number of workforce, especially project managers with adequate prior knowledge, curiosity, commitment and networks to key information. Studies by Hajizadeh and Zali (2016) found that prior knowledge has a positive and significant impact on both cognitive characteristics, that is, prior knowledge and alertness. George, Parida, Lahti and Wincent (2016) assert that if a person's level of alertness is high, opportunities can be identified even without actively searching for them or by simply observing the phenomena. This means that innovation within NGOs becomes vital in the workplace to enable them achieve competitive edge which leads to bigger opportunities. This can act as a catalyst that can make business, however it requires excellent project managers who are motivated to innovate and discover opportunities in the agro based sector which has not gotten the desired attention and it is a least researched area in social entrepreneurship (Porter \& Kramer, 2019). Most social organizations including agro based NGOs are cash starved and therefore achieving excellence at staffing obviously pose a challenge to ensure recruiting, training, appraising and compensating the paid staff. The NGOs at times have to rely on unpaid volunteers, who often are the lifeblood of cash-starved social organizations, (Bloom \& Chatterji, 2009). The NGOs are also caught in between fulfilling donor demands on spending and providing successful projects to beneficiaries. The insights from this literature are relevant for social entrepreneurial organizations and have laid ground on the NGOs landscape and challenges in Kenya and how these challenges can impact on their growth.

This paper sought to establish the relation between Opportunity discovery and growth of agro based NGOs in Kenya and it hypothesized that the dimensions of opportunity discovery have a positive influence in the level of growth of NGOs such that at high levels of them, growth is high, and at low levels, the growth is low. The rest of the study sections include literature review, research methodology, findings and conclusions.

\section{Literature Review}

In this section we review the main aspects of opportunity dimensions from both theoretical and empirical lenses. The study is based on the Kirznerian theory which focuses on alertness to opportunity discovery. It states that opportunities are created independent of the individual and thus available to all and are discovered by an alert individual (Kirzner, 1997). The theory is based on alertness (also known as discovery theory) as the fundamental quality of the entrepreneur. This theory asserts that entrepreneurship is all about discovering an unexploited or under-exploited opportunities and deciding to create a new business model within a new enterprise designed to profit from this discovered opportunity. Alertness triggers entrepreneurial activities which lead individuals to make discoveries that are valuable in the satisfaction of human wants. On the basis of this theory, the role of entrepreneurs lies in their alertness to previously unnoticed opportunities to discover and exploit situations in which they are able to sell for high prices that which they can buy for low prices (Kirzner, 2015). The implication of this theory to the current study is that discovering the existence of the opportunity differentiates an entrepreneur from a non-entrepreneur and therefore entrepreneurial NGOs are more alert to discover unnoticed opportunities to previously opportunities. The Kirznerian theory implies that it is the NGOs with a critical mass of alert employees that are able to trigger entrepreneurial activities which lead individuals to discover opportunities in the sector that are valuable to better serve the society and therefore justify their need for continued funding.

The Social network theory supports the relationships between organizations and entrepreneurial opportunity discovery (Busenitz, et al., 2003). The theory stipulates that, an individual's interpersonal networks, including weak-tie networks and strong-tie networks, facilitate the access to diverse information that benefits learning and information dissemination processes to further discover opportunities. The existence of conditions conducive to opportunity discovery includes possession of relevant skills and entrepreneur experience which is very important to a social entrepreneur, not everyone can have skills to discover opportunities, and a social entrepreneur needs prior knowledge and alertness as well as networks of contacts and relations in order to facilitate the discovery process (Kirzner, 1997; Shane \& Venkataraman, 2000). Craig and Lindsay (2001) assert that most successful entrepreneurs are opportunity focused and most of them believe they have a special sensitivity or alertness towards opportunities. Ardichvili, Cardozo and Ray (2003) aver that, individuals who possess prior knowledge about something have a better chance of recognizing opportunities than those who lack such knowledge. Scholars have argued that entrepreneurial opportunity discovery is a kind of learning process that utilizes one's tacit knowledge (Dutta \& Crossan, 2005; Lumpkin \& Lichtenstein, 2005; Marvel \& Lumpkin, 2007). Consequently, an entrepreneur's unique possession of knowledge enables him or her to identify certain opportunities that others neglect. Thus, an 
entrepreneur's social level of alertness and prior knowledge about existing opportunities has a positive correlation with the number and success of entrepreneurial initiatives discovery.

The theory implies that the agro based NGO that have prior knowledge and good networking to key sources of information are able to discover opportunities and exploit them better to achieve their objectives in the society which fundamentally is to help out the common man. They do so through poverty reduction initiatives. There is little consensus over how to define and measure performance in NGOs since these organizations have unclear goals and uncertain relationship between programs' activities and outcomes (Carman, 2007). Miller (2007) viewed performance measurement as a program assessment method that can be used to evaluate efficiency and effectiveness of a social entrepreneurship initiative program and its impact. On this basis, growth performance in this study is operationalized as Partnership efficiency, Fundraising efficiency and Project non-financial efficiency. The current study examined the link between these Opportunity Discovery dimensions and growth performance of NGOs as the dependent variable based on the Kirzenian theory. A number of studies have been undertaken linking opportunity Discovery dimensions and firm Growth as a measure of organizational performance in different sectors including Non-Governmental ones. In a study; Entrepreneurial opportunity recognition: an empirical study of R\&D personnel by Yu-Lin Wang and other scholars, their results show that an individual's prior knowledge, social networks, and perception about the industrial environment on opportunities all had positive effects on entrepreneurial opportunity recognition which further contributed significantly to individual-level innovation performance. A study on theory of entrepreneurial opportunity identification and development by Ardichvili et al., (2003) demonstrated that both strong-tie and weak-tie social networks have a positive impact on the entrepreneurial opportunity discovery process. Ardichvili, et al., (2003) pointed out the following basic knowledge as essential for entrepreneurs when it comes to recognizing opportunities: special interest knowledge and general industry knowledge; prior knowledge of markets; prior knowledge of customer problems; and prior knowledge of ways to serve markets. Fatima, Iqbal, Rehman and Ali (2011), in a study of factors affecting opportunity recognition process: case study of Pakistan, found the antecedents of opportunity recognition to be entrepreneur's social networks, entrepreneurial alertness to business, past work experience, prior knowledge, efficient search and second-hand learning. On the contrary, Grecu (2014), in his study of factors stimulating the process of entrepreneurial opportunity recognition, focused on the external factors like socio-political factors, the industry and market characteristics, and the networks formed within them and finally the entrepreneur. Hajizadeh and Zali (2016), in their study on prior knowledge, cognitive characteristics and opportunity recognition', found that prior knowledge has a positive and significant impact on both cognitive characteristics, that is, prior knowledge and alertness. Puhakka (2007), in his study on effects of opportunity discovery strategies of entrepreneurs on performance of new ventures, the results illustrate that the performance of new ventures is strongly influenced by opportunity discovery strategies used by entrepreneurs. Salvador, Pinot de Villechenon and López Rizzo (2014), in their study on European SMEs and the Brazilian market: The key role of social networks, the results highlighted the importance of social networks for the SMEs interviewed.

Although the literature has explored both the theoretical and empirical precursors that influence entrepreneurial opportunity Discovery dimensions and therefore potential firm growth performance, there is limited empirical research that has examined the linkage between entrepreneurial opportunity discovery dimensions and growth in NGOs specifically in agricultural subsector in Kenya. This study endeavored to empirically fill this information gap.

\section{Research and Methodology}

In this section the methodology used to investigate the link between opportunity discovery and growth is discussed. Opportunity discovery was conceptualized as Social Network, Alertness and Prior Knowledge and NGOs growth was conceptualized as nonfinancial efficiency, fundraising efficiency and partnership efficiency. Likert scale dominated the study to gauge how strongly respondents agree or disagree with a statement regarding the three dimensions of Opportunity Discovery. The hypothesized conceptual frame work is as shown in figure 1.

\section{Entrepreneurial opportunity discovery dimensions}

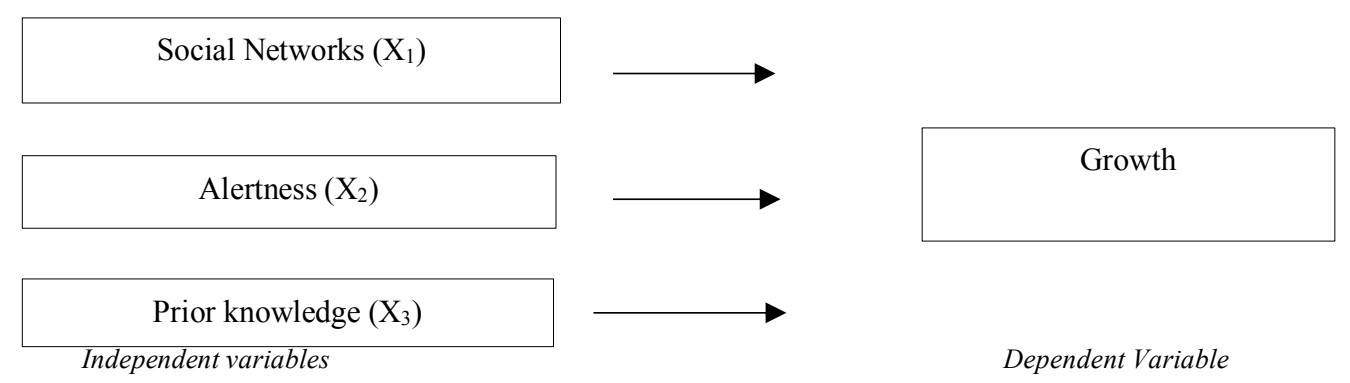

Figure 1: Conceptual model 


\section{Sampling and data collection}

The study adopted a causal approach which required the use of statistical estimation techniques to fit the model used to draw conclusions on the objectives of the study. This was achieved by the use of inferential statistics for analysis and hypothesis testing. The following hypotheses were tested:

$\mathrm{H}_{01-}$ Social networks have no significant influence on NGOs growth.

$\mathrm{H}_{02}$-Alertness has no significant influence on NGOs growth.

$\mathrm{H}_{03}$ - Prior knowledge has no significant influence on NGOs growth.

This study adopted a census technique which scholars like Israel (2012) and Grim, et al., (2010) advocated for in the case of a small population (200 or less). The sample size was135 NGOs in agriculture subsector. To conduct credible Structural Equation Modelling (SEM) analysis, sample size requirement was also put into consideration. Robert et al., (2001) purport that SEM has flexibility strength but with the flexibility, it is difficult to develop generalized sample size requirements guidelines. Various rules of thumb that include sample sizes below 100 have been advanced. Considering the proposal by Nunnally (1967), of 10 cases per latent variable, the size of 135 respondents considered on the study was found to be adequately above the requirement for 4 latent variables $(10 \times 4=40)$. Self- administration approach was to collect primary data. Structural Equation Modeling (SEM) was used for hypothesis testing. The SEM procedure involved development of the fit measurement model to first ascertain the model structure prior to converting it to structural model to test the relationships among model variables. However prior to conducting the SEM analysis, the tests of assumptions were undertaken initially, that is, linearity, multicolinearity, Heteroscedascitiy and normality assumptions were all tested.

\section{Linearity}

The study tested the linearity assumption using curve estimation approach because the Maximum Likelihood Estimator (MLE), in which same estimation is used, assumes that the relationship among variables does not deviate significantly from linearity. In curve estimation procedure, the F-statistics was computed for a pair of variables. Linearity of relationship is achieved when the $p$ values is significant $(\mathrm{p}<.05)$ (MacCallum, Widaman,Zhang \& Hong, 1999). The results of the ANOVA test of linearity showed all $p$ values above .05 confirming no significant deviation from linear relationships (constant slope) between the predictor variables and the dependent variable and therefore data did not require any transformation during SEM analysis.

\section{Multicollinearity}

Variance Inflation Factors (VIFs) was used to test for multicollinearity and the results showed that VIF values were all less than the threshold maximum value of 5.The VIFs for the three independent variables were found to range between 1.222 and 1.488 as indicated in Table 1,thus implying that, the three dimensions of Opportunity Discovery caused unique variance in the growth of agro based NGOs in Kenya .In this regard, the value and contribution of each dimension on growth was uniquely and separately assessed.

Table 1: Multicollinearity test results

\begin{tabular}{|c|c|c|}
\hline & \multicolumn{2}{|c|}{ Collinearity statistics } \\
\hline & Tolerance & VIF \\
\hline \multicolumn{3}{|l|}{ (Constant) } \\
\hline Risk Taking & .712 & 1.405 \\
\hline Gains & .749 & 1.335 \\
\hline Market & .647 & 1.546 \\
\hline Technology & .774 & 1.292 \\
\hline Projects & .818 & 1.222 \\
\hline Networking & .672 & 1.488 \\
\hline Cognitive & .730 & 1.369 \\
\hline Knowledge & .695 & 1.438 \\
\hline Networking & .702 & 1.424 \\
\hline
\end{tabular}

Dependent variable: growth

Source: Authors' own calculation 


\section{Heteroscedasticity test}

Heteroskedasticity is present in the case when variable does not exhibit a constant variance across the range of the other variable and therefore lenders model estimation inaccurate across the range of predictor values. The BP and Koenker tested the null hypothesis that residuals do not exhibit Heteroscedasticity (residuals are homoscedastic). The computed P-values of the BP-LM test were greater than 0.05 implying that the study failed to reject the null hypothesis and concluded that residuals do not exhibit heteroscedasticity and therefore this is an evidence that prediction of growth using the derived model is more precise.

\section{Normality test}

Maximum likelihood estimation requires that the residuals of the fitted model follow a normal distribution and therefore the findings of the sample can be generalized to the entire population from which the sample was drawn. Therefore normality was tested using Shapiro-Wilk test in which a non-significant $p$-value of 0.820 was obtained. Non-significant $p$ values means that the deviation from normality is not significant ((Razali \& Wah, 2011). Initially univariate outliers was assessed using Skewness and kurtosis while multivariate outliers was assessed using Mahalanobis distance and deletion of the five univariate outliers and two multivariate outliers from the dataset improved the normality.

\section{Findings and Implications}

This study tested reliability of the research instrument as indicated in Table 2, to measure the internal consistency of the observed factors. Taber (2018), affirmed that the reliability value above (0.60) is acceptable, the reliability for social networks have (0.857), alertness is reliability value $(0.840)$ and prior knowledge has value $(0.861)$ while the highest value of growth is $(0.913)$. All the variables have reliability values above the threshold minimum (0.60) which implies that the results are trustable.

The measurement model of SEM examines each latent variable and its measurements (indicators). The results on the measurement model analysis for opportunity discovery is summarized in table 1 . The measurements for each construct were examined for reliability and validity. Reliability test was examined using Cronbach alpha which generated Cronbach alpha coefficients as asserted by (Taber, 2018), where reliability of each latent variable is attributed to a Cronbach alpha above 0.7 . All the variables in the study had Cronbach alpha statistics above 0.7 which showed that the questionnaire was reliable.

Construct validity of the latent were tested considering both convergent and discriminant validity. Construct validity is based on factor analysis results. All the indicators were found to all have loadings above 0.4 on the latent variables. Considering EFA, the KMO statistic opportunity discovery was found to be 0.799 which tends to one and Bartlett's chi-square statistics found to have a pvalue less than 0.05 . This implies compactness and that the factor analysis results were reliable. Average variance extractions for each latent variable were computed which were all found to be above 0.5 implying convergent validity. As shown in table 1 , all the square multiple correlations for each of the three constructs of Opportunity Discover and for growth construct, are less than the respective Average Variance Extracted (AVE) implying Discriminant Validity. The results confirmed construct validity and reliability of the measurements to the latent variables.

Table 2: Measurement model summary of entrepreneurial opportunity discovery dimensions

\begin{tabular}{lllll}
\hline Latent variable & Indicator & Loading & $\begin{array}{l}\text { Squared multiple AVE } \\
\text { correlations }\end{array}$ & Cronbach's
\end{tabular}

\begin{tabular}{|c|c|c|c|c|c|c|}
\hline \multirow[t]{9}{*}{ Opportunity Discovery } & \multirow[t]{3}{*}{ Social Networks } & SN1 & 0.780 & 0.47 & \multirow[t]{3}{*}{.693} & 0.857 \\
\hline & & SN2 & 0.731 & 0.63 & & \\
\hline & & SN3 & 0.567 & 0.21 & & \\
\hline & \multirow[t]{3}{*}{ Alertness } & ALERT1 & 0.767 & 0.58 & \multirow[t]{3}{*}{.640} & 0.840 \\
\hline & & ALERT2 & 0.647 & 0.626 & & \\
\hline & & ALERT3 & 0.507 & .282 & & \\
\hline & \multirow[t]{3}{*}{ Prior Knowledge } & PRIOK1 & 0.820 & .623 & \multirow[t]{3}{*}{.796} & 0.861 \\
\hline & & PRIOK2 & 0.786 & .437 & & \\
\hline & & PRIOK3 & 0.782 & .606 & & \\
\hline \multirow{3}{*}{\multicolumn{2}{|c|}{ Ngo Growth }} & NONFINACIAL & 0.895 & .816 & \multirow[t]{3}{*}{.849} & 0.913 \\
\hline & & FUNDRAISING & 0.863 & .515 & & \\
\hline & & PARTNERSHIP & 0.790 & .720 & & \\
\hline
\end{tabular}

Source: Authors own calculation

The fitness of the measurement model is indicated in table 3 . The $\chi 2$ statistic (48)=45.398 with a non-significant $p$ value of 0.580 indicates that there is no significant departure of the model from the data therefore the hypothesized measurement model of Opportunity Discovery Constructs and Growth provides a good fit of the data to the model since the fit measures are jointly within the threshold values. In particular, the fit measures GFI and RMSEA are .932 and .003 respectively indicating that data fitted the 
predicted model well. The two incremental fit indices NFI (.922) and CFI (.922) indicate that the model is $92 \%$ better than the null model. This shows good absolute fitness of model as shown in table 3.

Table 3: Model fit indices of opportunity discovery-growth model

\begin{tabular}{lllllllll}
\hline Name of fit statistics & $\chi \mathbf{2}$ & df & $\mathbf{P}$ & NFI & GFI & AGFI & CFI & RMSEA \\
\hline Fit value from model & 45.398 & 48 & .580 & .922 & .932 & .853 & .922 & .003 \\
\hline Fit threshold & ns & & & $\geq 0.80$ & $\geq 0.80$ & $\geq 0.90$ & $\geq 0.90$ & $\leq 0.08$ \\
\hline
\end{tabular}

Source: Author's own Calculation

The measurement model was converted to structural model to test relationship between Opportunity Discovery dimensions and growth as indicated in figure 2. The figure shows the standardized regression weights along the three structural paths and the latent variables and their respective observed indicators from each discovery dimensions (social networks, alertness and Prior Knowledge) to growth.

The rule of the thumb require that the Normed Fit Index (NFI) exceeds .90 (Byrne, 2013) or .95 (Lomax \& Schumacker Lomax, 2004). The Goodness of Fit Index exceeds .90 (Byrne, 2013). The Comparative Fit Index exceeds .9 (Byrne, 2013). RMSE is less than .08 (Brown \& Cudeck, 1993). The relative chi-square should be less than 2 or 3 (Kline, 1998). The fit indices jointly within the threshold value indicating that the structural model does not significantly departure from the data as indicated in Table 4 .

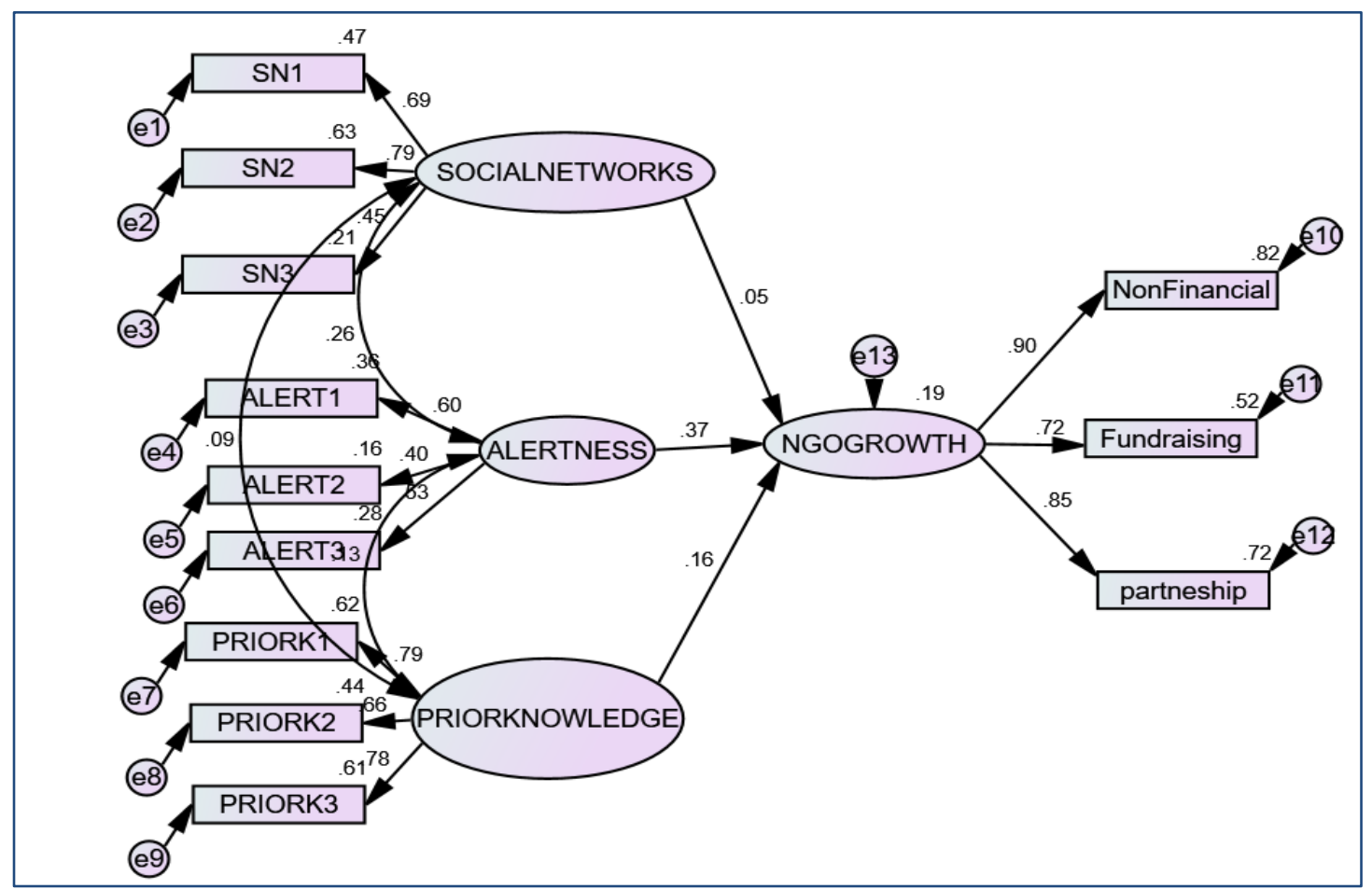

Figure 2: Path diagram to test the influence of the relationship between entrepreneurial opportunity discovery dimensions and growth model

The standardized (also unstandardized) regression coefficient estimates derived from structural model in figure 2 are shown in table 4. They are all positive therefore implying that Opportunity Discovery has positive influence on growth of agro based NGOs in Kenya. In particular, the standardized regression coefficients of Alertness $(\beta=0.372, \mathrm{p}=0.033)$ and Prior Knowledge $(\beta=0.163$, $\mathrm{p}=0.031$ ) have $\mathrm{p}$ values which are all less than the threshold maximum value of 0.05 meaning that alertness and prior knowledge have a positive significant influence on growth of agro based NGOs in Kenya. The hypotheses $\mathrm{H}_{02}$ and $\mathrm{H}_{03}$ are thus rejected. The results have provided evidence of the importance of entrepreneurial attitude of receptiveness to available opportunities in order to discover entrepreneurial opportunities which requires effective information search and positive perception of the environment. González, Husted and Aigner, (2017), in their study, 'Opportunity Discovery and Creation in Social Entrepreneurship: An exploratory study in Mexico' also used regression coefficient estimates to test their hypothesis. However, the regression weights results also shows that for social networks, the regression weight of 0.047 is not significantly different from zero since it has a $p$ value of $p=0.713$ meaning that social networks have no significance influence on growth of agro based NGOs in Kenya; therefore $\mathrm{H}_{01}$ fails to reject at 0.05 level of significance. 
Table 4: Standardized and unstandardized regression coefficient estimates of opportunity discovery dimensions

\begin{tabular}{|c|c|c|c|c|c|c|c|}
\hline & & & $\begin{array}{l}\text { Unstandardized } \\
\text { estimates }\end{array}$ & $\begin{array}{l}\text { Standardize } \\
\text { estimates }\end{array}$ & S.E. & C.R. & $\mathbf{P}$ \\
\hline NGO Growth & $<---$ & PRIORKNOWLEDGE & 0.261 & 0.163 & .120 & 2.175 & .031 \\
\hline NGO Growth & $<---$ & ALERTNESS & 0.974 & 0.372 & .458 & 2.128 & .033 \\
\hline NGO Growth & $<---$ & SOCIALNETWORKS & 0.123 & 0.047 & .333 & .368 & .713 \\
\hline SN3 & $<---$ & SOCIALNETWORKS & 1.000 & 0.454 & & & \\
\hline SN2 & $<---$ & SOCIALNETWORKS & 1.725 & 0.791 & .506 & 3.411 & $* * *$ \\
\hline SN1 & $<---$ & SOCIALNETWORKS & 1.483 & 0.686 & .407 & 3.638 & $* * *$ \\
\hline ALERT3 & $<---$ & ALERTNESS & 1.000 & 0.531 & & & \\
\hline ALERT1 & $<---$ & ALERTNESS & 1.720 & 0.603 & .651 & 2.643 & .008 \\
\hline PRIORK3 & $<---$ & PRIORKNOWLEDGE & 1.000 & 0.779 & & & \\
\hline PRIORK2 & $<---$ & PRIORKNOWLEDGE & 0.971 & 0.661 & .168 & 5.795 & $* * *$ \\
\hline PRIORK1 & $<---$ & PRIORKNOWLEDGE & 1.157 & 0.789 & .190 & 6.094 & $* * *$ \\
\hline NON-FINANCIAL & $<---$ & NGO Growth & 1.000 & 0.903 & & & \\
\hline FUNDRAISING & $<---$ & NGO Growth & 0.646 & 0.718 & .080 & 8.070 & $* * *$ \\
\hline PARTNERSHIP & $<---$ & NGO Growth & 0.907 & 0.849 & .095 & 9.581 & $* * *$ \\
\hline ALERT2 & $<---$ & ALERTNESS & 0.919 & 0.402 & .376 & 2.442 & .015 \\
\hline
\end{tabular}

Source: Authors own calculation

Table 5 indicates the hypothesis testing results of the study. The first null hypothesis $\mathrm{H}_{01}$ : social networks have no significant influence on agro based NGOs growth in Kenya. There was no statistical evidence to reject $\mathrm{H}_{\mathrm{O} 1}$ at $5 \%$ significant level. Therefore, it is concluded that social networks have no significant influence on NGOs growth in Kenya. However the results disagree with Ardichvili, Cardozo and Ray (2003) in their study 'A theory of entrepreneurial opportunity identification and development', demonstrated that both strong-tie and weak-tie of social networks have a positive impact on the entrepreneurial opportunity discovery.

The hypothesis $\mathrm{H}_{02}$ : Alertness has no significant influence on Agro based NGOs growth in Kenya was rejected and therefore concluded that alertness has a significant influence on growth of agro based NGOs in Kenya. This results resonates with the findings by Adomako, Danso, Boso and Narteh (2018) in their study 'Entrepreneurial alertness and new venture performance: facilitating roles of networking capability', found that increases in the levels of entrepreneurial alertness are related to increases in new initiative performance. Additionally, they found that under conditions of increased use of social and business networking capabilities, the effectiveness of entrepreneurial alertness as a driver of an organization success is amplified.

Regarding the third hypothesis, $\mathrm{H}_{03}$ : Prior knowledge has no significance influence on Agro based NGOs in Kenya, it was rejected based on the $p$ values of the regression coefficients which is less than .05. The study concluded that at $5 \%$ significant level, prior knowledge has a significant influence on growth of agro based NGOs in Kenya. The results imply that a workforce team that has critical level of prior knowledge in the sector are an asset to an NGO that if the environmental factors are encouraging can be exploited to discover new opportunities to enhance growth of the NGOs.

Table 5: Hypothesis testing results

\begin{tabular}{|c|c|c|c|c|}
\hline Hypothesis & Statistic & & $\begin{array}{l}\text { Sig. level (p- } \\
\text { value) }\end{array}$ & $\begin{array}{l}\text { Decisio } \\
\text { n }\end{array}$ \\
\hline $\begin{array}{l}H_{01} \text { Social networks have no significant influence on NGOs } \\
\text { growth. }\end{array}$ & $\begin{array}{l}\text { Coefficient } \\
=0.047\end{array}$ & estimate & 0.713 & $\begin{array}{l}\mathrm{H}_{01} \text { fail to } \\
\text { Reject }\end{array}$ \\
\hline $\mathrm{H}_{02}$ Alertness has no significant influence on NGOs growth. & $\begin{array}{l}\text { Coefficient } \\
0.372\end{array}$ & estimate $=$ & 0.033 & $\begin{array}{l}\mathrm{H}_{02} \\
\text { Rejected }\end{array}$ \\
\hline $\begin{array}{l}\text { H}_{03} \text { Prior knowledge has no significant influence on NGOs } \\
\text { growth }\end{array}$ & $\begin{array}{l}\text { Coefficient } \\
=0.163\end{array}$ & estimate & 0.031 & $\begin{array}{l}\mathrm{H}_{03} \\
\text { Rejected }\end{array}$ \\
\hline
\end{tabular}

Source: Authors own calculation

\section{Conclusions}

The findings highlighted in this paper provides promising growth direction for agro based NGOs in Kenya by developing a growth model with alertness and prior knowledge as significant factors underpinning growth. These results points that NGOs can be effective means through which social ills like poverty, unemployment and food insecurity which erodes the self-esteem of the underserved and power to participate in nation building can be addressed. However, this will come at a cost and requires entrepreneurial mindset. 
NGOS should enhance knowledge acquisition skills of new knowledge in order for them to develop entrepreneurial strategies that are geared towards addressing the social ills bedeviling developing countries like Kenya. In this regard, implementing procedures aimed at assisting employees with the process of seeking both technical and non-technical knowledge should be the way to go. Need to train them on the ever changing $21^{\text {st }}$ century technologies and other emerging issues in society.

The results indicates that if NGOs funders can support a program that creates and nurtures special alertness to opportunities among the NGO workforce, more opportunities can be discovered which will lead to greater capacity for the NGOs to implement programs benefiting the society. The funding partners can do so by supporting annual or biannual competitions to identify alertness among competitors or setting up more incubation centers that identifies and nurtures individuals. We believe that if these suggestions are implemented effectively, we will surely see reduction of cases of poverty levels, unemployment and food insecurity in Kenya and therefore building a better country with low unemployment and free from hunger with self-esteem citizens ready to participate in development of their country.

Although the paper encountered methodological limitation of focusing on one thematic area, at least it has contributed insightful information regarding entrepreneurial alertness, social networking and prior knowledge landscape in Kenya whose findings can serve as baseline for future studies.

\section{References}

Adomako, S., Danso, A., Boso, N., \& Narteh, B. (2018). Entrepreneurial alertness and new venture performance: facilitating roles of networking capability. International Small Business Journal, 36(5), 453-472. https://doi.org/10.1177\%2F0266242617747667

Aldashev, G., \& Navarra, C. (2018), Development NGOs: basic facts. Annals of public and cooperative economics, 89(1), 125-155 https://www.unamur.be/en/eco/eeco/pdf/1409.pdf.

Alvarez, S. A., \& Barney, J. B. (2014). Entrepreneurial opportunities and poverty alleviation. Entrepreneurship Theory and Practice, 38(1), 159-184.retrieved from: https://doi.org/10.1111\%2Fetap.12078

Ardichvili, A., Cardozo, R., \& Ray, S. (2003). A theory of entrepreneurial opportunity identification and development. Journal of Business venturing, 18(1), 105-123. https://doi.org/10.1016/S0883-9026 (01)00068-4.

Atkinson A. B., Backus P. G., Micklewright J., Pharoah C. And Schnepf S. V., 2012, 'Charitable giving for overseas development: UK trends over a quarter century', Journal of the Royal Statistical Society A, 175, 167-190.

Bloom, P. N., \& Chatterji, A. K. (2009). Scaling social entrepreneurial impact, California management review, 51(3), 114-133. https://centers.fuqua.duke.edu/case/wpcontent/uploads/sites/7/2015/02/Article_Bloom_ScalingSocialEntrepreneurialImpact 2009.pdf

Browne, M. W., \& Cudeck, R. (1993). Alternative ways of assessing model fit. Sage focus editions, 154, 136136.https://books.google.co.ke/books?hl=en\&lr=\&id=FvIxxeYDLx4C\&oi=fnd\&pg=PA136\&dq=Brown, + M., $+\% 26+$ Cude $\mathrm{ck},+$ R. $+(1993) .+$ Alternative + ways + of + assessing + model + fit. + K. + Bollen + and + J.\&ots $=$ MEy1YHwQ\&sig=rFvUot7aoWo_zAciNP1nTiFsUBw\&redir_esc $=\mathrm{y} \# \mathrm{v}=$ onepage\&q\&f$=\bar{f}=$ false

Busenitz, L. W., West III, G. P., Shepherd, D., Nelson, T., Chandler, G. N., \&Zacharakis, A. (2003). Entrepreneurship Research in Emergence: Past Trends and Future Directions. Journal of Management, 29(3), 285-308. https://doi.org/10.1016\%2FS0149-2063_03_00013-8

Byrne, B. M. (2013). Structural equation modeling with Mplus: Basic concepts, applications, and programming. Routledge. https://doi.org/10.4324/9780203807644

Carman, J. G. (2007). Evaluation practice among community-based organizations: Research into the reality. American Journal of evaluation, 28(1), 60-75.

Craig, J., \& Lindsay, N. (2001). Quantifying 'gut feeling'in the opportunity recognition process. Frontiers of entrepreneurship research, 124-137.

Duffield, M. (2012). Challenging environments: Danger, resilience and the aid industry, Security dialogue, 43(5), 5-492 https://journals.sagepub.com/doi/pdf/10.1177/0967010612457975

Dutta, D. K., \&Crossan, M. M. (2005). The Nature of Entrepreneurial Opportunities: Understanding the Process using the 4I Organizational Learning Framework. Entrepreneurship Theory and Practice, 29(4), 425-449. Retrivied from: https://doi.org/10.1111\%2Fj.1540-6520.2005.00092.x

Fatima, S., Iqbal, S., Rehman, F. U., \& Ali, M. (2011). A study of factors affecting opportunity recognition process-case study of Pakistan, an opportunity recognition process framework. Interdisciplinary Journal of Contemporary Research in Business, $3(8), 1106-1125$.

George, N. M., Parida, V., Lahti, T., \& Wincent, J. (2016). A systematic literature review of entrepreneurial opportunity recognition: insights on influencing factors. International Entrepreneurship and Management Journal, 12(2), 309-350.

González, M. F., Husted, B. W., \& Aigner, D. J. (2017), Opportunity discovery and creation in social entrepreneurship: An exploratory study in Mexico. Journal of Business Research, 81, 212-220. Retrieved: https://doi.org/10.1016/j.jbusres.2016.10.032

Grecu, I. (2014). Factors of Entrepreneurial Opportunity Recognition: A Systematic Review of Evidence in the Last Decade (Master's thesis) Retrieved from http://projekter.aau.dk/projekter/en/studentthesis/factors-of-entrepreneurial- 
opportunityrecognition-a-systematic-review-of-empirical-evidence-in-the-last-decade (3d177ae2-e 758-4902-9c54d23c3b5efff9).html

Grim, J., Hora, J., Boček, P., Somol, P., \&Pudil, P. (2010).Statistical Model of the 2001 Czech Census for Interactive Presentation, Journal of Official Statistics, 26(4), 67). retrived

from:https://www.researchgate.net/profile/Jii_Grim/publication/228859684_Statistical_Model_of_the_2001_Czech_Censu s_for_Interactive_Presentation/links/0fcfd507c02045c730000000/Statistical-Model-of-the-2001-Czech-Census-forInteractive-Presentation.pdf

Hajizadeh, A., \&Zali, M. (2016).Prior Knowledge, Cognitive Characteristics and Opportunity Recognition.International Journal of Entrepreneurial Behaviour \& Research, 22(1), 63-83. Retrieved from : https://doi.org/10.1108/IJEBR-05-2015-0110

Israel, G. D. (2012).Sampling: Determining sample size. University of Florida IFAS Extension: http://edis.ifas.ufl.edu/pd006

Kirzner, I. M. (1997). Entrepreneurial discovery and the competitive market process: An Austrian approach. Journal of economic Literature, 35(1), 60-85.

Kirzner, I. M. (2015). Competition and entrepreneurship. University of Chicago press.

Kline, R. B. (1998). Software review: Software programs for structural equation modeling: Amos, EQS, and LISREL. Journal of psychoeducational assessment, 16(4), 343-364, https://doi.org/10.1177\%2F073428299801600407

Lomax, R. G., \& Schumacker, R. E. (2004), A beginner's guide to structural equation modeling, psychology press. https://doi.org/10.4324/9781410610904

Lumpkin, G. T., \& Lichtenstein, B. B. (2005).The Role of Organizational Learning in the Opportunity-Recognition Process.Entrepreneurship Theory and Practice, 29(4), 451-472. https://doi.org/10.1111\%2Fj.1540-6520.2005.00093.x

Lumpkin, G. T., Moss, T. W., Gras, D. M., Kato, S., \&Amezcua, A. S. (2013). Entrepreneurial Processes in Social Contexts: How are they Different, if at all? Small Business Economics, 40(3), 761-783. https://link.springer.com/article/10.1007/s11187011-9399-3

MacCallum, R. C., Widaman, K. F., Zhang, S., \& Hong, S. (1999). Sample size in factor analysis. Psychological methods, $4(1), 84$.

Marvel, M. R., \& Lumpkin, G. T. (2007).Technology Entrepreneurs' Human Capital and Its Effects on Innovation Radicalness.Entrepreneurship Theory and Practice, 31(6), 807-828.Of Small Business \&Entrepreneurship, 21(2), 139-151. https://doi.org/10.1111\%2Fj.1540-6520.2007.00209.x

Mary George, N., Parida, V., Lahti, T. et al. Int Entrep Manag J (2016) 12: 309. https://doi.org/10.1007/s11365-014-0347-y

Miller, J. (2007). An effective performance measurement system: Developing an effective performance measurement system for city of Elmira sub-grantees. Unpublished manuscript, New York: Binghamton University, State University of New York.

Nunnally, J. C., \& Bernstein, I. H. (1967). Psychometric theory (Vol. 226). New York: McGraw-Hill. Retrieved from : http:/garfield.library.upenn.edu/classics1979/A1979HZ31300001.pdf

Porter, M. E., \& Kramer, M. R. (2019). Creating shared value. In managing sustainable business (pp. 323-346). Springer, Dordrecht http://www.nuovavista.com/SharedValuePorterHarvardBusinessReview.PDF

Puhakka, V. (2007).Effects of Opportunity Discovery Strategies of Entrepreneurs on Performance of New Ventures.The Journal of Entrepreneurship, 16(1), 19-51.

Razali, N. M., \& Wah, Y. B. (2011). Power comparisons of shapiro-wilk, kolmogorov-smirnov, lilliefors and anderson-darling tests. Journal of statistical modeling and analytics, 2(1), 21-33. Retrieved from :

https://www.researchgate.net/profile/Bee_Yap/publication/267205556_Power_Comparisons_of_Shapiro-

Wilk_Kolmogorov-Smirnov_Lilliefors_and_Anderson-Darling_Tests/links/5477245b0cf29afed61446e1/PowerComparisons-of-Shapiro-Wilk-Kolmogorov-Smirnov-Lilliefors-and-Anderson-Darling-Tests.pdf

Robert C. MacCallum, Keith F. Widaman, Kristopher J. Preacher \& Sehee Hong (2001) Sample Size in Factor Analysis: The Role of Model Error, Multivariate Behavioral Research, 36:4, 611-637, DOI: 10.1207/S15327906MBR3604_06

Shane, S., \& Venkataraman, S. (2000). The Promise of Entrepreneurship as a Field Of Research.Academy Of Management Review, 25(1), 217-226 https://doi.org/10.5465/amr.2000.2791611

Shane, S., Locke, E. A., \& Collins, C. J. (2003). Entrepreneurial motivation. Human Resource Management Review, 13(2), 257279. https://doi.org/10.1016/S1053-4822(03)00017-2

Salvador, E., Pinot De Villechenon, F., \&López Rizzo, H. (2014). European Smes and the Brazilian Market: The Key Role of Social Networks. European Business Review, 26(4), 368-388.

Taber, K. S. (2018). The use of Cronbach's alpha when developing and reporting research instruments in science education. Research in Science Education, 48(6), 1273-1296. https://doi.org/10.1007/s11165-016-9602-2 